\author{
ADAM OLEKSIUK \\ ORCID https://orcid.org/0000-0003-1796-8125 \\ Szkoła Główna Handlowa w Warszawie
}

\title{
TADEUSZ CZACKI JAKO EKONOMISTA Z WOŁYNIA. SELEKTYWNY PRZEGLĄD DOROBKU
}

\section{Tadeusz Czacki as an Economist from Volhynia. Selective Review of Achievements}

WyraZy KLuCzowe: Tadeusz Czacki, Wołyń, Gimnazjum Wołyńskie, ekonomia polityczna, polityka fiskalna (podatkowa), polityka monetarna, handel międzynarodowy, edukacja ekonomiczna

KeYwords: Tadeusz Czacki, Volhynia, Volhynian school (the Liceum Krzemienieckie), political economy, fiscal (tax) policy, monetary policy, international trade, economic education

Aвstract: Tadeusz Czacki (1765-1813) was born in Volhynia. He was a Polish economist, historian, educator, bibliographer, numismatist, creator and organizer of the Volhynian school. From among the numerous works he published this publication focuses only on the economic themes of his writings. The most important views and postulates advocated by Tadeusz Czacki regarding economy are discussed, including tax and monetary issues and Poland's international trade with selected partners. An important contribution of the analysed author were also his efforts to develop statistical reporting of Poland. The study presents Tadeusz Czacki as an economist, economic activist, propagator of economic knowledge and a precursor of its teaching in the Volhynian school (the Liceum Krzemienieckie).

Verba volant, scripta manent.

\section{Wprowadzenie}

Tadeusz Czacki, którego uważa się za propagatora w Polsce m.in. nowoczesnego systemu podatkowego i wolnego handlu, prowadził badania dotyczące możliwości wymiany towarowej z Turcją i Mołdawią. Celem niniejszego opracowania jest przedstawienie dorobku naukowego Czackiego dotyczącego problematyki ekonomicznej. W kwestiach gospodarczych Czacki zabierał dosyć często głos, jednak jego poglądy w tej materii są mniej znane i rozpowszechniane w środowisku akademickim. W swoich dziełach wielokrotnie powtarzał, że silne państwo jest nierozłącznie związane z siłą gospodarczą. Niniejsza praca pokazuje, jak ważne i jednocześnie prekursorskie, oczywiście w warunkach polskich, były poglądy Czackiego 
w zakresie ekonomii politycznej. Należy podkreślić rolę jego wkładu w tym obszarze dla XVIII- i XIX-wiecznej Polski, choć dzisiaj niedocenionego i zapomnianego. Dla okresu, w którym żył i tworzył Czacki, a także dla kolejnych pokoleń, w tym kontynuatorów i wychowanków, jego prace miały charakter inkluzywny, tj. powszechny, i były początkiem ważnej ogólnonarodowej dyskusji na temat przyszłości Polski. Czacki na pewno nie był indyferentny na sprawy gospodarcze, ale angażował się w nie. Jego dzieło można określić słowami samego Czackiego: „Kto krok czyni ku dobremu, już ma zasługę, bo ośmiela następców, bo wskazał przykład" (Dzieła Tadeusza Czackiego 1845/3, 457).

\section{Krótki rys biograficzny Tadeusza Czackiego}

Tadeusz Czacki urodził się w 28 sierpnia 1765 r. w miejscowości Poryck na Wołyniu, w rodzinie szlacheckiej (herb Świnka), natomiast zmarł 8 lutego 1813 r. w Dubnie, również na Wołyniu. Był polskim działaczem gospodarczym, ekonomistą, historykiem, pedagogiem, bibliografem, numizmatykiem, a także członkiem Komisji Edukacji Narodowej, jednym z twórców Konstytucji 3 maja oraz współzałożycielem warszawskiego Towarzystwa Przyjaciół Nauk, założycielem Biblioteki Poryckiej, głównym twórcą i organizatorem Gimnazjum Krzemienieckiego (nazywanego "Atenami Wołyńskimi”) i ostatnim starostą niegrodowym nowogrodzkim, sprawującym urząd w latach 1786-1792 (Knot 1937, 144-146; Węglicka 2015a; 2015b; Danowska 2006, 17-23).

Czas jego edukacji przypadł na okres oświecenia, a w związku z tym nauki pobierał w domu rodzinnym, od F. Grodzickiego. Swoją zawodową karierę rozpoczą w $1781 \mathrm{r}$. jako praktykant w sądzie nadwornym w Warszawie, ale w tym samym czasie studiował również zbiory Biblioteki Załuskich. Dzięki temu poznał się z J. Albertrandim oraz A. Naruszewiczem, a jednocześnie król wyznaczył go do realizacji uporządkowania części prywatnego archiwum królewskiego oraz Metryki Koronnej. Dzięki wykonaniu zadań związanych z powierzonymi mu funkcjami zyskał uznanie w środowisku naukowym i już w 1784 r. został działaczem Komisji Kruszcowej. Z kolei dwa lata później, bo w 1786 r., był członkiem Komisji Skarbu Koronnego, jak również członkiem oraz działaczem Kompanii Solnej. Jego praca oraz oddanie sprawom państwa spowodowały, że w tym samym roku został nagrodzony tytułem kawalera Orderu Świętego Stanisława (Knot 1937, 144-146; Węglicka 2015a; 2015b; Danowska 2006, 17-23).

Kolejnym istotnym etapem kariery państwowej Czackiego była wizyta na Wawelu w 1791 r., gdzie dokonał otwarcia grobów królewskich Zygmunta Starego oraz Zygmunta Augusta. W efekcie prowadzonych prac zabrał stamtąd cenne pamiątki, przeprowadził spis klejnotów zlokalizowanych w skarbcu królewskim oraz zabrał czaszkę, która według niego należała do Jana Kochanowskiego, a następnie 
przekazał ją w darze księżnej Izabeli Czartoryskiej (Knot 1937, 144-146; Węglicka 2015a; 2015b; Danowska 2006, 17-23). „Pierwsze kroki na polu działalności publicznej ujawniły w Czackim zdolności finansisty, uczonego, ekonomisty-prawnika, historyka i pedagoga" (Krausha 1901).

W 1792 r. Czacki został odznaczony Orderem Orła Białego. W tym samym roku, ze względu na swoje zainteresowanie podróżami, założył towarzystwo żeglugowe o nazwie Czacki, Drzewiecki i spółka. Z kolei w 1803 r. z uwagi na fakt, że szkolnictwo polskie na Litwie i Rusi uzyskało autonomię, mianowano go wizytatorem szkół na obszarze guberni wołyńskiej, kijowskiej oraz podolskiej. W związku z tym zaangażował się w pracę na rzecz szkolnictwa. „Posiew, rzucony przez Czackiego na niwę naukowości i oświaty polskiej, wydał niespożyty owoc" (Krausha 1901). Czacki był założycielem w 1805 r. polskiej szkoły w Krzemieńcu na Wołyniu (zwanej inaczej Gimnazjum Wołyńskim lub Liceum Wołyńskim). Na jej inaugurację wygłosił przemówienie, które poruszało m.in. kwestie niepodległości państwa polskiego i konieczność edukowania się Polaków (Czacki 1805). Powody powołania szkoły polskiej w Krzemieńcu przez Czackiego wyjaśnia m.in. M. Danielewiczowa

[...] nurtować poczynały w społeczeństwie tendencje wyrównywania zaległości, pragnienia przyswojenia nowych zdobyczy wiedzy, zwłaszcza z zakresu nauk matematyczno-przyrodniczych i ekonomicznych i związana z tym potrzeba uczenia się języków nowożytnych (Danielewiczowa 1937, 59)

i na kolejnych stronicach swojego opracowania dodaje:

otwarcie Gimnazjum Wołyńskiego poprzedziła akcja propagandowa, wyreżyserowana po mistrzowsku przez Czackiego. Oto powstaje szkoła „celniejsza”, polski Oxford czy Cambridge, tu będzie ognisko twórczej myśli badawczej na Wołyniu, te mury będą służyć nie tylko oświacie, ale i nauce (Danielewiczowa 1937, 68).

W Warszawie w dowód zasług dla Czackiego w 1876 r. powołano do życia Liceum Ogólnokształcące im. Tadeusza Czackiego, jedną z najstarszych szkół średnich w stolicy Polski, charakteryzującą się od początku swojego powstania wysokim poziomem nauczania i kontynuującą tradycję gimnazjum w Krzemieńcu.

\section{Problematyka ekonomiczna w dorobku Tadeusza Czackiego}

Działalność Czackiego była szeroka. Napisał on wiele artykułów na różne tematy, w tym (co mniej jest rozpoznane) dotyczące: handlu, ekonomii i gospodarki. Podobne prace sprowadzał również z zagranicy do gimnazjum w Krzemieńcu: „uzupełniono w stopniu zadawalającym [...] dział ekonomii politycznej" (Danielewiczowa 1937, 90). 
Wśród prac napisanych przez Czackiego, w ramach których problematyka gospodarcza była w mniejszym bądź większym wymiarze zarysowana, wymienić należy przede wszystkim kilka ważnych dzieł, znajdujących się w wydaniach zbiorowych jego opracowań. Niektóre artykuły Czackiego zostały publikowane np. w „Dzienniku Handlowym” z 1788 r. (m.in. „Raport o poszukiwaniach solnych za Stanisława Augusta od roku 1780") (Danowska 2009).

Do najważniejszych jego prac o charakterze ekonomicznym ${ }^{1}$ należy zaliczyć następujące opracowania (Dzieła Tadeusza Czackiego T. 3 1845):

- „Statystyka Polski”

- „O dziesięcinach w powszechności a w szczególności w Polsce i Litwie, i o koniecznej potrzebie utworzenia zamiany snopowej Dziesięciny na osep zbożowy"

- „O rzeczy menniczej w Polsce i na Litwie dla uczniów Wolynskiego Gymnazium (pisana roku 1810)”

- „O monecie polskiej i litewskiej”

- „O handlu Polski z Portą Ottomańską (pisana r. 1792)”.

We wszystkich wyżej wymienionych opracowaniach Czacki poruszał się w obszarze ekonomii politycznej, którą uważał za ważny element odbudowy państwa polskiego. Należy jednak podkreślić, że jego poglądy w zakresie ekonomii i gospodarki skupiały się z jednej strony na interpretacji przeszłych doświadczeń, które mogłyby służyć za wzór dla Polaków, z drugiej zaś formułował postulaty zmian w zakresie przede wszystkim swobody w wymianie towarowej, polityki fiskalnej (podatkowej) i monetarnej. Czackiemu chodziło o to, aby w jak najlepszy możliwy sposób gospodarka podległego wtedy kraju mogła dynamicznie się rozwijać. Warto zasygnalizować fakt, że jego dorobek nie funkcjonował w oderwaniu od naukowych organizacji ówczesnej nauki. Działalność ta wiązała się bowiem w dość ścisły sposób np. z członkostwem w Towarzystwie Przyjaciół Nauk, w którym od początku uważano go na wybitnego działacza oraz naukowca. Czacki miał bogate zbiory książek, co pozwalało wpisać go w modny ówcześnie nurt walki o naprawę ojczyzny i przebudzenie świadomości narodowej obywateli poprzez szerzenie wiedzy historycznej, ekonomicznej i prawniczej (Danowska 2009). Uważał on, że szerzenie wiedzy z zakresu ekonomii politycznej jest istotne, o czym pisze $\mathrm{w}$ liście do Hugona Kołłątaja: „kurs ekonomii politycznej zostanie się na rok przyszły” (Hugona Kołłątaja korrespondencya listowna T. 3 1844, 231). Autor omawiając zakres tematyczny zajęć, które będą prowadzone w nowo tworzonej szkole w Krzemieńcu, stwierdza, iż na języku francuskim i nauce moralnej nauczyciel

wyłoży [...] sposoby, za pomocą których te charaktery bez żadnej z siebie samych działalności malują wyobrażenia i stają się tłumaczeniam naszego czucia, co go przywiezie

${ }^{1}$ Prace Tadeusza Czackiego zostały zebrane i wydane przez Edwarda Raczyńskiego, który napisał przedmowę do nich. Dzieła Czackiego znajdują się w domenie publicznej Biblioteki Narodowej. 
do wywodu teoryi dziewięciu części, czyli pierwiastków wchodzących w ekonomię mowy (Hugona Kołłątaja korrespondencya listowna T. 3 1844, 217).

Czacki nie tylko popierał rolę i znaczenie wiedzy ekonomicznej dla ówczesnej sytuacji politycznej i gospodarczej państwa podległego oraz jego odrodzenia, ale także sam gromadził liczne książki z zakresu ekonomii politycznej (Hugona Kołłątaja korrespondencya listowna T. 3 1844, 20-56). Przede wszystkim były to pozycje w języku łacińskim; w jego zbiorach można się natknąć na liczne dzieła pisane przez biskupów, m.in. „nopolitańskich”, oraz prace z archiwów „poznańskiej i kujawskiej kapituły”, a także „krakowskiej decezyi” (Dzieła Tadeusza Czackiego T. 3 1845, 6). Ważne źródło stanowiły również zgromadzone różne inwentarze, takie jak np. inwentarz „Szawelskiej ekonomii” z 1546 r., czy międzynarodowe traktaty handlowe. Czacki korzystał też ze zbiorów m.in. Józefa hrabiego Ossolińskiego, o którym pisze: „W licznych dziełach o rzeczach ojczystych, bez udziału Jego skarbów, pisma zostałyby niedokładnemi" (Dzieła Tadeusza Czackiego T. 3 1845, 6).

Czacki uważał bowiem, że wszelkie zebrane materiały umożliwią stworzenie nowego, silnego gospodarczo państwa polskiego. Zwrócił uwagę, iż w zgromadzonej literaturze ekonomicznej można znaleźć sprawdzone przepisy na praktyczne wdrożenia w zakresie prowadzonej polityki gospodarczej. Poniżej zaprezentowano selektywny przegląd jego dorobku ekonomicznego.

Pracą wpisującą się w tematykę ekonomiczną w dorobku Czackiego było opracowanie „Statystyka Polski” (Dzieła Tadeusza Czackiego T. 3 1845, 1-30). $\mathrm{Na}$ jego pierwszych stronicach opisywał m.in. „Ludność w proporcji rozciągłości”, „Proporcje różnych klas w Polsce” czy też „Stosunek ludności do rozciągłości ziemi w wziętym przykładzie w okolicach Warszawy" (Dzieła Tadeusza Czackiego T. 3 1845, 4-6). W paragrafie 6 autor analizuje „Fabryki w stosunku ludności kraju i potrzeb rolnictwa" (Dzieła Tadeusza Czackiego T. 3 1845, 6-7). W części 7, zatytułowanej "Jakie są fabryki, i w jakim względzie wystarczają potrzebie narodu i społeczności domowej" (Dzieła Tadeusza Czackiego T. 3 1845, 7), przybliża proces produkcji wełny i sukna w ówczesnej Polsce, co prezentuje w poniższych słowach:

Gospodarz ma owce, wełnę sprzedając, a sukno kupując znajduje ogromną różnicę między ceną wełny, którą sprzedał, a kupionem suknem; pozna więc, że dogodniej dla niego, wyrabiać $\mathrm{z}$ własnej wełny. Z pomnożeniem warsztatów, monopolium w kupnie wełny jest niepodobnem, i bilans między dającym i biorącym wełnę już utrzymuje wagę między właścicielem owcy a właścicielem warsztatu (Dzieła Tadeusza Czackiego T. 3 1845, 7).

W dalszej części swojej pracy konstatuje, że Wielkopolanie byli od zawsze ważnym producentem sukna, które sprzedawali m.in. do Chin. Jednocześnie opisuje, że Ukraina „wszystko sukno kupowała w Wielkiej Polsce albo zagranicą” (Dzieła Tadeusza Czackiego T. 3 1845, 7). W kolejnej części swojego dzieła „Statystka Polski” 
o znamiennym tytule „Która część kraju, w jakiej epoce, i w jakim względzie powinna być ulepszoną" stwierdza:

Wielu województw [...] nie w równym postępie czasu ulepsza się stan dóbr, azatem kraju, lecz nagle podniesienie ma związek z powiększoną massą pieniądza, spokojnością kraju, bezpieczeństwem osobistem, opieką prawa nad handlem, ułatwieniem odbytu produktów i różnymi miejscowymi okolicznościami (Dzieła Tadeusza Czackiego T. 3 $1845,8)$.

Dostrzega więc zróżnicowanie rozwoju społeczno-gospodarczego w poszczególnych częściach kraju. Z punktu widzenia współcześnie prowadzonej statystyki ciekawe (acz anachroniczne) jest stwierdzenie:

W piśmie statystycznym niemożna szczególnych robić tablic, lecz gdy prawdy wyrażone trafią do przekonania i zyskają wiarę, wtenczas zrobić każdy może potrzebne stosunki (Dzieła Tadeusza Czackiego T. 3 1845, 9).

Czacki porównując różne części kraju, jest świadom ich nierówności w zakresie poziomu życia obywateli. Wyraził to w następujący sposób:

Cena żyta na naszą monetę fl. 1,5 w Krakowie około $1360 \mathrm{r}$. było toż samo co na Podlasiu około 1564 r.; w wyższym Wołyniu około 1750 r., na Ukrainie około 1770 r. i nawet cokolwiek później. A tak cena żyta krakowskiego i cena onegoż na Podlasiu taż sama była o dwa wieki różnicy, a na Wołyniu o cztery wieki (Dzieła Tadeusza Czackiego T. 3 1845, 9).

Autor jednocześnie zauważa, robiąc i prezentując wyliczenia, iż w okresie od 1625 do 1788 r. najszybciej rozwijała się gospodarka oraz poziom i jakość życia obywateli (co rozumie przez ilość posiadanych przez obywateli dóbr) w okolicach Warszawy (Dzieła Tadeusza Czackiego T. 3 1845, 9-10).

W kolejnej kluczowej dla Czackiego pracy „O dziesięcinach w powszechności a w szczególności w Polsce i Litwie, i o koniecznej potrzebie utworzenia zamiany snopowej Dziesięciny na osep zbożowy" (Dzieła Tadeusza Czackiego T. 3 1845, 30-80) autor nie tylko zawarł analizę ekonomiczną funkcjonowania tegoż narzędzia podatkowego na terenie kraju („kiedy była wprowadzana dziesięcina, nieznano tak wielkich i tak różnych podatków”) (Dzieła Tadeusza Czackiego T. 3 1845, 73), lecz także przeanalizował w sposób szczegółowy przepisy na temat podatków w Polsce, Litwie oraz Rusi. W podrozdziale „Czyli Litwa i Ruś, z prawa, jak mówią, powszechnego, podlega ciężarowi dziesięcin, i czyli równej powinności Mazowsze jest poddane” konstatował: „Ruś i Litwa najwięcej podlegała wschodniego kościoła prawidłom. W kościele wschodnim nie było dziesięcin, więc i w Litwie i w ruskich krajach jej nie było" (Dzieła Tadeusza Czackiego T. 3 1845, 38). 
O Mazowszu, które - jak pisał Czacki - różni się od pozostałych części kraju, zauważa: „w względzie Mazowsza zupełnie przeciwne są uwagi” (Dzieła Tadeusza Czackiego T. 3 1845, 41). W swojej pracy objaśniał, czym są dziesięciny:

Były one ciężarem (dziesięciny - przyp. A. O.), kiedy cena pracy była mała, a nakładów na odrodzenie ziemioplodów prawie nie znano. Stały się przykrzejszemi, kiedy rolnik pracą i owocem nakładu zaczął się dzielić. Broniono i odmawiano dziesięciu z równą natarczywością. Ten, co odbierał dziesięcinę, i ten co ją dawał, chciał być sprawy swojej sędzią. Naznaczono ten wydział z ziemiopłodów, bez uwagi, że może przyjdzie ten moment, kiedy ogromny kapitał będzie celniejszym środkiem do ulepszenia i utrzymania gospodarstwa; a zatem biorący tę dziesiątą część z produktów, które się odradzają, bierze tym samym i dziesiątą część nakładowego kapitału. Naznaczono równie umowy o zamianę snopowych dziesięciu na pieniądze, nie zastanawiając się, że kiedy wszystkie produkta podnoszą się w cenie pieniędzy, a żyto i owies zawsze jednakowo wyżywieniu człowieka, części bydła w naszym kraju służy, zatem kapłan na samych pieniężnych dziesięcinach mający fundusz, musi mieć kiedyżkolwiek nędzę w udziale (Dzieła Tadeusza Czackiego T. 3 1845, 30).

Czacki krytykuje duchowieństwo w rozdziale 5 pt. „O dziesięcinach z nowin, i z jakiego powodu biskupi dla wielu dziesięcin z nowin w Polsce przyswoili sobie prawo", o których pisze:

aby zrobić dzieło dokładne o dziesięcinach, i uniknąć zarzutu, który był mi czyniony, iż pisząc o niech w moim dziele, opuściłem ten szczegół, jako tylko należących do kwestyi, kto ją ma brać, pisać cokolwiek w tej mierze i teraz przedsięwziąłem, zwłaszcza że mówiąc o potrzebie zgody pasterzów ludu z ludem, ośmielę się przełożyć, że prawa do wielu nowinnych dziesięcin dla biskupów, nie są tak mocne, jak się na pierwszy rzut oka zdają (Dzieła Tadeusza Czackiego T. 3 1845, 49),

a następnie dodaje: „Opór świeckich, natrętność duchownych w wymaganiu od dziesięciny, zbyt daleko posunęły w Polsce" (Dzieła Tadeusza Czackiego T. 3 1845, 62). Czacki proponuje więc w rozdziale 9 pt. „O konieczności utworzenia umów o dziesięciny”, a następnie w rozdziale 10, zatytułowanym „O prawidłach ugody, zmiany w kwestii płacenie dziesięcin”, przedkłada ugodę ogólnospołeczną, co zawarł w następujących słowach:

Rozumiem, że biorący i dający dziesięcinę przekonać się powinien, iż nie jest rzeczą rozważną zaprzeczać ten ciężar, ani jest podobną, aby dziesięciny były w tym sposobie na dalszy czas utrzymane. Trzeba więc początek dziewiętnastego wieku uczynić tym punktem, w którym na przeszłość spuści się zasłona, a wzajemna na przyszłe pokolenia będzie ustanowiona dogodność. Kiedy w czasie trwania egzystencyi Polski przekładałem potrzebę tej ugody, czynione uwagi, układany projekt, przynoszę jako ważną część dziejów, mniemań w ekonomice politycznej. Czuję, że trzeba godzić interessa rolnika 
z duchownemi, w niektórych miejscach panów z włościanami, samych duchownych nawet między sobą, nakoniec wezwać opieki rządowej. Z prostotą w sercu, a zupełną czystością zamiarów odważam myśli moje wystawić (Dzieła Tadeusza Czackiego T. 31845,75$)$.

Na podkreślenie zasługuje więc fakt, że to ważne, a zarazem krytyczne wobec niektórych warstw społecznych, dzieło Czackiego dotyczące dziesięcin miało za cel przeorganizowanie prawa podatkowego, co według autora ostatecznie przełoży się na funkcje gospodarcze i ekonomiczne całego kraju. Pod tym względem znaczenie tej pracy należy widzieć jako co najmniej, jak na tamte czasy, istotne, gdyż jest znany fakt, iż jego projekt w niektórych regionach kraju został przyjęty, stał się także na obszarze zarządzanym przez Prusy podstawą do przeprowadzonej tam reformy systemu podatkowego.

W pracy pt. „O monecie polskiej i litewskiej” podejmuje problematykę znajdujących się w obiegu monet na terytorium Polski i Litwy. Na wstępie Czacki zauważa:

Wielu w tej mierze pisało. Ja prócz wyjaśnienia i kilku szczęśliwych odkryć cudzą $\mathrm{w}$ wielu rozgałęzioną pracę w moje przenoszę dzieło, i używam owoców własnych uwag, które powinność urzędu w kommissyi skarbowej zebrać kazała (Dzieła Tadeusza Czackiego T. 1 1843, 129-201).

Na dalszych stronicach pracy prezentuje „Wykład tablic monet polskich i litewskich” (Dzieła Tadeusza Czackiego T. 1 1843, I-XXVII)². Podobna tematyka, acz poświęcona jedynie Litwie, znajduje się w opracowaniu „Wykład. Tablicy monet kuficznych znajdowanych w Litwie, od gminu zakładem przymierze z czartem nazwanych" (Dzieła Tadeusza Czackiego T. 2 1844, 134-147, I-VI). Kontynuację tych rozważań zawarł w materiale zatytułowanym „O rzeczy menniczej w Polsce i na Litwie dla uczniów Wolynskiego Gymnazium” (pisana roku 1810) (Dzieła Tadeusza Czackiego T. 3 1845, 364-455), w którym zajął się polityką monetarną. Na wstępie Czacki pisze „Urządzenie monety jest ważną częścią nauki skarbowej” (Dzieła Tadeusza Czackiego T. 3 1845, 365). Na kartach swojego opracowania omawia historyczne uwarunkowania powstania monety w Polsce i na Litwie. Autor stwierdza: „Dowiedliśmy jestestwo monety Polskiej od Bolesława Chrobrego" (Dzieła Tadeusza Czackiego T. 3 1845, 389). Czacki dowodzi więc, że monety w Polsce pojawiły się mniej więcej w tym samym okresie co w innych częściach Europy, np. w Anglii i Szkocji w IX i X w. płaciło się bydłem, np. krowami, czy skórami („W Anglii i Szkocyi dość długo była moneta żyjącą") (Dzieła Tadeusza Czackiego T. 3 1845, 394). W Irlandii np. płacono rybami i owcami:

\footnotetext{
${ }^{2}$ Brak ciągłości numeracji, w tej część pracy występuje numeracja rzymska. Łacznie ta część opracowania składa się z 13 tablic.
} 
Nie masz tedy nic osobliwego, że w kraju wówczas niezmiernie zarosłym, futro pomagało handlowi, jeden lokieć sukna wyrównywa wartości dwóch ryb dwufuntowych (Dzieła Tadeusza Czackiego T. 3 1845, 395).

Niektóre monety wybijane były na „cienkiej blaszce”, inne na skórze, niektóre na papierze (Dzieła Tadeusza Czackiego T. 3 1845, 396). Jednak największą zasługą Czackiego w omawianej tematyce jest prezentacja całego systemu monetarnego zarówno tego obowiązującego w Polsce, jak i na Litwie. Czacki dokonał analizy porównawczej wartości pieniądza na tych terytoriach. Wykorzystał w tym celu również swoją szeroką wiedzę numizmatyczną i zainteresowania dotyczące różnych monet. Pod tym względem wykorzystywał polskie źródła archiwalne. Podstawę jego rozważań stanowiła kwestia czasu, w jakim pojawił się w obu państwach system monetarny. W swoim dziele autor prezentuje więc różne rodzaje pieniądza, które funkcjonowały, ich szacunkowe wartości, opisuje pochodzenie np. grosza a także sygnalizuje ówczesną specyfikę form płatności.

Ważnym dziełem w dorobku piśmienniczym Czackiego jest praca z zakresu handlu międzynarodowego pt. „O handlu Polski z Portą Ottomańską” (pisana r. 1792) (Dzieła Tadeusza Czackiego T. 3 1845, 327-352). W opracowaniu tym Czacki omawia handel zagraniczny Polski z imperium osmańskim. Autor zadaje następujące pytanie: „Co Polska ma za produkta, które państwo Ottomańskiemu dodawać może?” (Dzieła Tadeusza Czackiego T. 3 1845, 327). Czacki pisze: „Kilkanaście tylko rachuje się artykułów, które południowe Polski za granicę wyprzedają” (Dzieła Tadeusza Czackiego T. 3 1845, 327). Te kilkanaście produktów, o których wspomina autor, to płody rolne (ich wykaz zawarty jest w Aneksie 1 do dzieła Czackiego).

Autor omawia trudności, jak również ułatwienia we wzajemnych stosunkach handlowych, w tym traktaty i zawarte umowy handlowe. Zastanawia się: „Czy jest i którego państwa interessem, handlowi Polskiemu z Portą czynić przeszkody?" (Dzieła Tadeusza Czackiego T. 3 1845, 327). Sposób prowadzenia handlu Czacki podsumowuje następująco:

Dwojaki sposób jest prowadzenie handlu: jeden wodny, drugi lądowy. Dniestr pruje Podolskie i Braclawskie Województwo, łączy swe wody z Czarnem morzem w Alkiermanie inaczej Białygród zwanym. Dniepr między Oczakowem i Kinburnem w toż samo wpada morze. Boh równie swoje w te strony prowadzi nurty (Dzieła Tadeusza Czackiego T. 3 1845, 329).

W dalszej części dzieła omawia handel z Mołdawią. Autor docenia możliwości prowadzenia handlu z tym państwem, stwierdzając:

Bilans handlu z tym krajem okazuje: iż wszystkie produkta moldawskie i Woloskie, wyjąwszy wina i lojów są nam albo koniecznie potrzebne, jako sól: albo kupione, drożej przedawane bydź mogą. Ten handel najlepszy był dla Polski zyskiem, bo zbytku niepomnażał, a konkurrencyą potrzebnego do utrzymania dni ludzkich produktu, soli czynił. 
Nie znała Moldawia taryff celnych; do wielości wozów stosowano clo, a najczęściej arędujący celnik stawał się losu kupca panem (Dzieła Tadeusza Czackiego T. 3 1845, 335).

Swoboda wymiany handlowej między Polską a Mołdawią jest według Czackiego wartością samą w sobie. Jednak autor dostrzega także pojawiające się trudności, gdy pisze:

Moldawia i Woloszczyzna jest jednym krajem, acz różnym rządzona sposobem, z państwem Tureckiem. Clo więc nie może być brane dwa razy, od kupców idących w państwa Tureckie; to jest: przy wchodzie do Moldawii i Woloszczyzny, i wyjściu z tych prowincyji pod imieniem cla lub tranzytu (Dzieła Tadeusza Czackiego T. 3 1845, 337).

Czacki kilkukrotnie podkreśla na kartach swojej pracy konieczność dalszego rozwoju handlu z Mołdawią. W dalszej części opracowania konstatuje, że Rosja, Anglia, Francja wynegocjowały sprawiedliwe/równe dla siebie warunki handlu z Turcją, w związku z czym również Polska powinna żądać równych praw, jeśli chodzi o handel z Turcją: „Jako zaś Polska ma żądać tych samych swobód, których inne faworyzowane narody doznają" (Dzieła Tadeusza Czackiego T. 3 1845, 343). Zauważa także, że wszystkie prawa odnośnie do handlu z Portą Ottomańską, które znajdują się w różnych aktach prawnych, należy ująć w jeden traktat handlowy (Dzieła Tadeusza Czackiego T. 3 1845, 339). Na kartach swojej pracy w podrozdziale "Co i jakie nam warunki handlowe upewniły, i w czem żądać należy dodatku lub objaśnienia?” (Dzieła Tadeusza Czackiego T. 3 1845, 339-350) w 49 punktach proponuje warunki handlowe, które powinny obowiązywać $\mathrm{w}$ relacjach $\mathrm{z}$ Turcją.

Na takowych dwóch prawidłach ugruntowanym, naród życzyć winien uskutecznienia tych żądań, które tu się wykładają, a wsparcie ich bądź swemi, bądź cudzych państwach traktatami, w notach zostaje dla gruntownego dowodu wyjaśnionem (Dzieła Tadeusza Czackiego T. 3 1845, 339).

Postuluje całkowitą wolność w handlu na Morzu Czarnym i Morzu Białym. Reasumuje to następującymi słowami: „Wolno być ma wszystkim Polakom, i nawzajem Turkom prowadzić bez żadnej przeszkody, mieszkanie gdzie chcieć, zakładać, podatku haraczu nie opłacając".

W ostatniej części swojej pracy: „Czyli jest którego mocarstwa interesem przeszkadzać handlowi Polski, na morzu Czarnem” Czacki dochodzi do wniosku, że fakt ożywienia handlu na Morzu Czarnym jest po części zasługą Francji. Co prawda Francja ma zawarty traktat handlowy z Rosją, ale jak pisze Czacki: „krótkiej trwałości” (Dzieła Tadeusza Czackiego T. 3 1845, 351). Autor dodaje: „Wszystkich produktów, co ma Polska potrzebuje Francya, a nawzajem Polska jej produkta konsumować będzie". Państwem, które nie jest zainteresowane rozwojem handlu na Morzu Czarnym, może być według Czackiego Anglia, co wyraża w następujących słowach: 
Przeto jest rzeczą obojętną dla Anglii, czy nasze sterty gnić będą, a interessem bydź się zdaje konkurrencyą z Rossyą ożywić, handel Chersonu osłabić, i zyski spodziewane tego mocarstwa umniejszyć (Dzieła Tadeusza Czackiego T. 3 1845, 351-352).

Bardzo ważnym faktem dotyczącym prac naukowych Czackiego jest to, że zarówno treści poświęcone dziesięcinom (podatkom), handlowi, jak i statystyce polskiej były elementami szerzej rozumianych projektów reform gospodarczych. Ich założenia w dużej mierze opierały się na wiedzy z zakresu historii gospodarczej, co stanowiło ważny argument tegoż autora w trakcie wystąpień publicznych, kiedy uzasadniał proponowane przez siebie koncepcje jako słuszne i mające swoje uzasadnienie w już stosowanej praktyce. Podkreślał jednocześnie, że wszelaka wiedza jest podstawą nie tylko do poznania dziejów własnego państwa, lecz także filarem, na którym powinna opierać się teraźniejszość i przyszłość (Langier 1999-2001, 145-157). W koncepcji Czackiego na temat przyszłości gospodarczej i ekonomicznej kraju wyraźne było negowanie zachowań ówczesnej i przeszłej szlachty (Langier 1999-2001, 145-157).

W późniejszych latach swojej działalności naukowej i edukacyjnej skupił się na bardziej praktycznych aspektach gospodarczych oraz edukacyjnych kraju. Dążył do doskonalenia systemu nauczania, wskazując na szczególne znaczenie w nim nauki, jaką jest ekonomia i prawo. Upatrywał więc rozwoju społecznogospodarczego w znajomości tych dziedzin przez obywateli, w efekcie czego wprowadził w szkole w Krzemieńcu wykłady z elementami ekonomii i prawa, które - co warto podkreślić - często przygotowywał samodzielnie (Danielewiczowa 1937). Jak pisze Danielewiczowa: „miał stale przed oczyma katastrofalny stan i poziom podręczników szkolnych - i wszystkim brakom na raz pragnął zapobiec") (Danielewiczowa 1937, 71).

\section{Podsumowanie i wnioski}

Reasumując, należy zauważyć, że dorobek naukowy Czackiego jest bardzo obszerny i wielotematyczny. Był on uczonym, działaczem i pedagogiem oświecenia, ale wszechstronne zainteresowania upodabniają go do przedstawicieli epoki renesansu. Za życia zgromadził wiele książek, zbiorów, które uchronił przed zniszczeniem. Mimo faktu, iż sprowadzał dzieła z zagranicy, brak w jego opracowaniach odniesień do współczesnych Czackiemu wybitnych ekonomistów, jak np. A. Smith (Frydrychowicz 1959, 297-319) ${ }^{3}$ czy Th. Malthus, chociażby w kwestiach związanych $\mathrm{z}$ handlem. Jest to o tyle ciekawe, że czytając np. Czackiego „O handlu Polski z Portą Ottomańską” z 1792 oraz dzieło Smitha „Badania nad naturą i przyczynami bogactwa

\footnotetext{
${ }^{3} \mathrm{Na}$ język polski Adama Smitha, Thomasa Malthusa przełumaczył ekonomista Stanisław Kłokocki (który znał się z Tadeuszem Czackim z działalności z Towarzystwa Warszawskiego Przyjaciół Nauk).
} 
narodów" z 1776 r. (2015), widać podobieństwa w zakresie prezentowanego przez obu autorów podejścia do np. wolnego handlu. Również problematyka podatkowa wydaje się zbieżna (w swoim dziele „O dziesięcinach..." Czacki identycznie jak we wcześniejszej pracy Smitha pisze, że „wszyscy członkowie społeczeństwa powinni płacić podatki") (Zabieglik 2002, 30). Powstaje pytanie, czy to możliwe, aby Czacki nie znał dzieła Smitha i dlaczego w jego opracowaniach nie ma o nim wzmianki chociażby w przypisach? Wydaje się to mało prawdopodobne ze względu na fakt, że ekonomię polityczną Smitha na salony w Polsce wprowadził jezuicki ksiądz Michał Ossowski (1743-1799); nastąpiło to już w latach osiemdziesiątych XVIII w. W 1787 r. król Stanisław August nawet uhonorował Ossowskiego medalem z napisem dictus novas comercii Patrii, w dowód zasług dla wytyczenia nowych szlaków dla polskiego handlu (Zabieglik 2002, 37). A przecież Czacki w swoich dziełach dużo miejsca poświęcił właśnie tematyce ekonomii politycznej. Również nie ma żadnych odniesień w pracy Czackiego „Statystyka Polski” do bardzo głośnej pozycji Malthusa „Prawo ludności” (Malthus 2013), która ukazała się w 1798 r., mimo iż jeden z paragrafów opracowania Czackiego pt. „Fabryki w stosunku ludności kraju i potrzeb rolnictwa" (Dzieła Tadeusza Czackiego T. 3 1845, 6-7) w dość, co prawda, luźny i niepełny sposób, ale jednak nawiązuje do wyznawanych poglądów przez Malthusa (Malthus 2013). Powstaje pytanie, jaka może być przyczyna pomijania tak ważnych, a przecież współczesnych Czackiemu, autorów? Należy zauważyć, że dorobek Czackiego w zakresie problematyki ekonomicznej ma charakter przyczynkarski i sprawozdawczy. Jednak biorąc pod uwagę okres, w jakim tworzył, i miejsca, w których żył i pracował, należy jego wysiłki uznać mimo wszystko za wyróżniające się, wartościowe i społecznie cenne. W jego opracowaniach z zakresu ekonomii politycznej dostrzec można pewne braki przejawiające się w dość słabym, a często chaotycznym opisie źródeł informacji gospodarczych, z których korzystał. Natomiast interesujące jest umieszczenie przez Czackiego na końcu niektórych swoich prac indeksu autorów wraz z tytułami ich opracowań, czyli „Rejestru Autorów w tym dziele wzmiankowanych oraz z wyrażeniem ich dzieł” (zabieg tego typu ułatwia czytelnikom dotarcie do szukanych materiałów). Badając treści jego dzieł z zakresu ekonomii politycznej, można dostrzec brak staranności w opisach bibliograficznych i przypisach, w podawaniu źródeł, co budzi pewne obawy o pochodzenie danych czy faktów. Konkludując, problematyka ekonomiczna nie była obca Czackiemu, co zaowocowało próbami jej prezentowania, a także interpretowania w wybranych pracach. Czacki podejmował starania, aby przenieść swoją wiedzę w omawianym zakresie bezpośrednio na procesy związane z zarządzaniem państwem, a także aby wprowadzać do nauczania w Gimnazjum Wołyńskim w Krzemieńcu osiągnięć m.in. ekonomii politycznej. Silną gospodarkę uważał za warunek konieczny, aby naród oraz kraj mogły wydostać się z zaborów obcych mocarstw. W związku z tym jego różnorodną działalność przejawiającą się w postaci prac 
o charakterze naukowym oraz przedsięwzięcia edukacyjne, których celem było petryfikowanie wiedzy ekonomicznej, należy uznać za wysoce pożyteczne dla ówczesnej Polski.

\section{Bibliografia}

Czacki, T. (1805), Mowa Jasnie Wielmoznego Tadeusza Czackiego [...] dnia 1 octobra 1805 roku, przy otwarciu Gymnazium Wołynskiego w Krzemiencu, miana. URL: http://ebuw.uw.edu.pl/ dlibra/doccontent?id=136991.

DANiElEwiczowa, M. (1937), Życie naukowe dawnego Liceum Krzemienieckiego, Wydawnictwa Kasy im. Mianowskiego Instytutu Pobierania Nauki. Warszawa. URL: http://dlibra.bibliotekaelblaska. $\mathrm{pl} /$ dlibra/doccontent?id=24273\&from=FBC.

DanowsKa, E. (2006), Tadeusz Czacki 1765-1813. Na pograniczu epok i ziem. W: Rozprawy Wydziału Historyczno-Filozoficznego, 17-23.

DanowsKa, E. (2009), „Dziennik Handlowy” 1786-1793 w świetle literatury przedmiotowej. W: Rocznik Historii Prasy Polskiej. XII, 89-106.

Dzieła Tadeusza Czackiego, т. 1 (1843), zebrane i wydane przez Edwarda Raczyńskiego. Poznań. URL: https://polona.pl/item/dziela-tadeusza-czackiego-t-1,NzkzMTkz/3/\#info:metadata.

Dzieła Tadeusza Czackiego, T. 2 (1844), O litewskich i polskich prawach, o ich duchu, źródłach, związku i o rzeczach zawartych w pierwszym statucie dla Litwy 1529, zebrane i wydane przez Edwarda Raczyńskiego. Poznań. URL: https://polona.pl/item/dziela-tadeusza-czackiego-t2,NzkyOTY0/146/\#info:metadata.

Dzieła Tadeusza Czackiego, т. 3 (1845), zebrane i wydane przez Edwarda Raczyńskiego. Poznań. URL: https:/polona.pl/item/dziela-tadeusza-czackiego-t-3,Nzk1NDA0/2/\#info:metadata.

FrYdrychowicz, G. (1959), Stanisław Kłokocki: w kręgu Puław. W: Pamiętnik Literacki: czasopismo kwartalne poświęcone historii i krytyce literatury polskiej. 50/3-4, 297-319.

Hugona Kołłątaja korrespondencya listowna: z Tadeuszem Czackim, Wizytatorem Nadzwyczajnym Szkół w Guberniach Wołyńskiej, Podolskiej i Kijowskiej przedsięwzięta w celu urządzenia Instytutów Naukowych i Pomnożenia Oświecenia Publicznego w trzech rzeczonych guberniach, T. 3 (1844), z rękopismu wydał Ferdynard Kojsiewicz. Kraków. URL: https://polona.pl/item/x-hugona-kollatajakorrespondencya-listowna-z-tadeuszem-czackim-wizytatorem,ODE4MjQ5Mjc/4/\#info:metadata.

Knot, A. (1937), Czacki Tadeusz (1765-1813). W: Polski słownik biograficzny. IV-1/16, 144-146.

Krausha, A. (1901), Tadeusz Czacki. W: Krausha, A., Album biograficzne zasłużonych Polaków i Polek wieku XIX, T. I. Warszawa. URL: https://pl.wikisource.org/wiki/Album_biograficzne_ zas $\%$ C5\%82u\%C5\%BConych_Polak\%C3\%B3w_i_Polek_wieku_XIX/Tom_pierwszy/ са $\% \mathrm{C} 5 \% 820 \% \mathrm{C} 5 \% 9 \mathrm{~B} \% \mathrm{C} 4 \% 87$.

Langier, C. (1999-2001), Tadeusz Czacki jako historyk. W: Prace Naukowe Wyższej Szkoły Pedagogicznej w Częstochowie. 8/10, 145-157.

Malthus, T. R. (2013), Prawo ludności. Warszawa.

Sмiтh, A. (2015), Badania nad naturą i przyczynami bogactwa narodów. Warszawa.

WęGLICKA, K. (2015a), Wielcy Kresowiacy. Warszawa.

WĘGLICKA, K. (2015b), Polacy z Kresów. Znani i nieznani. Warszawa.

Zabieglik, S. (2002), Adam Smith's Political Economy in Poland. Review of the Problem. W: Argumenta Oeconomica. 2(13), 30-37. 
